\title{
Status of meat alternatives and their potential role in the future meat market $-\mathrm{A}$ review
}

\author{
Hyun Jung Lee', Hae In Yong' ${ }^{2}$, Minsu Kim', Yun-Sang Choi ${ }^{2}$, and Cheorun Jo ${ }^{1,3, *}$
}

* Corresponding Author: Cheorun Jo Tel: +82-2-880-4804, Fax: +82-2-873-2271,

E-mail: cheorun@snu.ac.kr

1 Department of Agricultural Biotechnology, Center for Food and Bioconvergence, and Research Institute of Agriculture and Life Sciences, Seoul National University, Seoul 08826, Korea

2 Research Group of Food Processing, Korea Food Research Institute, Wanju 55365, Korea

${ }^{3}$ Institute of Green Bio Science and Technology, Seoul National University, Pyeongchang 25354, Korea

ORCID

Hyun Jung Lee

https://orcid.org/0000-0002-6891-8008 Hae In Yong

https://orcid.org/0000-0003-0970-4496 Minsu Kim

https://orcid.org/0000-0001-7038-1732

Yun-Sang Choi

https://orcid.org/0000-0001-8060-6237

Cheorun Jo

https://orcid.org/0000-0003-2109-3798

Submitted Jun 19, 2020; Revised Jul 2, 2020; Accepted Jul 20, 2020

\begin{abstract}
Plant-based meat analogues, edible insects, and cultured meat are promising major meat alternatives that can be used as protein sources in the future. It is also believed that the importance of meat alternatives will continue to increase because of concerns on limited sustainability of the traditional meat production system. The meat alternatives are expected to have different roles based on their different benefits and limitations. Plant-based meat analogues and edible insects can replace traditional meat as a good protein source from the perspective of nutritional value. Furthermore, plant-based meat can be made available to a wide range of consumers (e.g., as vegetarian or halal food products). However, despite ongoing technical developments, their palatability, including appearance, flavor, and texture, is still different from the consumers' standard established from livestock-based traditional meat. Meanwhile, cultured meat is the only method to produce actual animal muscle-based meat; therefore, the final product is more meat-like compared to other meat analogues. However, technical difficulties, especially in mass production and cost, remain before it can be commercialized. Nevertheless, these meat alternatives can be a part of our future protein sources while maintaining a complementary relationship with traditional meat.
\end{abstract}

Keywords: Meat Alternatives; Plant-based Meat Analogues; Edible Insects; Cultured Meat; Protein Sources

\section{INTRODUCTION}

Meat can be defined as "the flesh of an animal destined for our consumption as food" and includes edible parts of animal carcass, such as lean meat, fat, intestines, etc. [1,2]. Historically, as a food resource, meat has contributed to human evolution and development [3]. Meat is composed of essential nutrients, especially proteins, which are necessary for various physiological functions in the human body [4]. It provides approximately $15 \%$ of the proteins consumed in our diet and contains all the essential amino acids as well as various fatty acids and micronutrients (e.g., vitamin B complex, $\mathrm{Fe}, \mathrm{Zn}$, and Se) [5,6]. Moreover, meat protein has high digestibility with a corrected amino acid score reaching 0.92 [3]. In addition, it is flavorful and known to have important social and cultural meanings in human society [79]. Therefore, without doubt, meat is not only an important food for humans but is also an essential part of our lives.

Currently, the world population is growing fast and will reach 9 billion by 2050 [10]. It is estimated that we will need at least doubled amounts of meat compared to those we are producing now. This rapid increase in the global demand for meat is attributed not only to population growth, but also to economic development of developing countries [11,12]. Taking these factors into consideration, we have to shortly find a way to increase the production of meat. Earlier, industrialization of livestock farming fulfilled the increasing demand 
for meat and its products [10]. However, it is no longer possible to increase meat production for future demands because of the limited land and water resources for sustainability of livestock farming, rapid increase in animal welfare issues, and undesirable impact on the environment and climate changes [1]. Based on the gap between future demand and the present capability to supply meat, there is an increasing need for producing meat alternatives as protein sources. Furthermore, expansion of halal and kosher markets will also require the development of meat alternatives instead of livestock-based traditional meat, as the number of people consuming such foods might exceed $30 \%$ of the world population by 2025 [13].

Consequently, several efforts have been made to increase the production of conventional meat and/or different meat alternatives (Table 1) [10]. Among them, plant-based meat analogues, edible insects, and cultured meat are garnering the interest of most consumers, although cultured meat is still under development for commercialization. Therefore, in this review, the major meat alternatives (e.g., plant-based meat analogues, edible insects, and cultured meat) are introduced as promising protein sources that can be utilized in the near future for supporting and complementing the limited sustainability of the traditional meat production system.

\section{PLANT-BASED MEAT ANALOGUES}

\section{Definition and present features}

Plant-based meat analogues can be manufactured using protein extracted from plants [10]. Wheat, soybean, legumes, oil seeds, and fungi are known to be the main sources of plantbased meat analogues (Table 2) [13]. In fact, plant protein is one of the oldest food sources in our history. Tofu was first consumed in $965 \mathrm{CE}$, and several products, including wheat gluten, yuba, and tempeh, have been used for decades in different countries and regions [14,15]. Moreover, plant-based products have been suggested as a meat substitute since 1888 . However, most of them had very different characteristic features compared to traditional meat, especially with respect to flavor and texture. Therefore, these products did not succeed

Table 1. Types and definition of meat alternatives as a protein source

\begin{tabular}{ll}
\hline Types & Definition \\
\hline $\begin{array}{l}\text { Conventional meat } \\
\text { Plant-based meat analogue }\end{array}$ & $\begin{array}{l}\text { Traditional meat from farm animals } \\
\text { Meat analogue made of plant and fungus } \\
\text { proteins }\end{array}$ \\
Edible insect & $\begin{array}{l}\text { Insect used as food resources } \\
\text { Cultured meat }\end{array}$ \\
Modificial meat produced using stem cell \\
technology \\
3D-printed meat & Meat from genetically modified animals \\
& $\begin{array}{l}\text { Fabricated meat made of native or non-native } \\
\text { food materials with 3D printing system }\end{array}$ \\
\hline
\end{tabular}

Modified from Bonny et al [10]; Dick et al [80].
Table 2. Plant proteins used for plant-based meat analogues

\begin{tabular}{ll}
\hline Plant & Protein \\
\hline Wheat, rye, and barley & Gluten (Gliadins, Glutenins) \\
Soybean & $\beta$-conglycinin \\
Legumes & Glycinin, Vicilin \\
Oil seeds & Legumin, Albumins, Globulins, Glutelins \\
Fusarium venenatum & Mycoprotein \\
(Filamentous fungus) & \\
\hline
\end{tabular}

Adapted from Asgar et al [13].

in the market until the 1900s: the consumption of plant-based meat analogues was only limited to its economic benefits and social demands related to health, religion, and ethical reasons; however, its consumption did not have a pleasurable effect as far as flavor and texture were concerned [13].

In recent times, the market for plant-based meat analogues is expanding with increasing social demands, and constant efforts are being taken to improve their sensory qualities [14, 15]. Introduction of texturized vegetable protein (TVP) produced using various ingredients led to the development of plant-based meat analogues; currently, it occupies the biggest market among the different meat alternatives, and it is believed that the market will increase to over $\$ 21.23$ billion US dollars by 2025 [14,15].

\section{Benefits as meat alternatives}

The major reason for meat consumption is to obtain nutrition [13]. Thus, it is very important to manufacture plantbased meat analogues to meet the nutrient specifications of traditional meat [16]. In general, plant protein is limited in nutritional value because of the lack of several essential amino acids such as lysine, methionine, and/or cysteine, and has low bioavailability [17].

Based on their nutritional values and functions, wheat gluten and soybean proteins are the most-used sources among different plant proteins to prepare plant-based meat analogues [13]. Wheat, containing $8 \%$ to $17.5 \%$ proteins, is one of the most important crops. Gluten (subdivided into gliadin and glutenin) from wheat can be produced during the wet processing of flour and is approved as "Generally Recognized as Safe" (GRAS) grade. When it is heated above $85^{\circ} \mathrm{C}$, gluten can be coagulated, resulting in gel formation without loss of its structural order. Moreover, as gluten can form a cohesive blend between protein and the other ingredients, it can be utilized as a plant protein to produce meat analogues. Meanwhile, soybean protein is derived from leguminous plants, as are clover, peas, and alfalfa. It is recently attracting the interest of consumers as a good protein source with economic benefits. Malav et al [18] reported that soybeans have $35 \%$ to $40 \%$ of high-quality proteins, $15 \%$ to $20 \%$ of fats, $30 \%$ carbohydrates, as well as $\mathrm{Fe}, \mathrm{Ca}, \mathrm{Zn}$, and vitamin $\mathrm{B}$ groups. Liu et al [19] suggested that soybean protein can be used as an alter- 
native to meat products because of its excellent capacity for rehydration, oil absorption, emulsification, and water absorption.

In the current market, several products are successful as plant-based meat analogues and seem to provide sufficient amount of proteins to our diet as meat alternatives. Bohrer [14] investigated the nutritional contents in four major types (beef burger products, beef meatballs, pork ham, and chicken nuggets) of traditional meat and plant-based meat analogues in market. They found that each beef patty in a burger contains $23.33 \mathrm{~g}$ of protein, whereas a meat analogue patty has approximately $19.46 \mathrm{~g}$ of protein (Figure 1). However, plantbased meat analogues have less cholesterol and more dietary fiber, which can be appealing to consumers. The other types of products (beef meatballs, pork ham, and chicken nuggets) also showed similar overall results (See Bohrer [14] for more detailed information). Therefore, as far as nutritional aspects are concerned, especially the protein contents, plant-based meat analogues are likely to be good substitutes to traditional meat. The products will be beneficial to consumers who cannot eat traditional meat and meat products, mostly owing to their religious and ethical beliefs. In particular, when considering the massive market expansion for halal and kosher food products as well as the increasing interest in animal welfare, among the various meat alternatives, protein sources devoid of animal protein will be in high demand as plant-based meat analogues in the future.

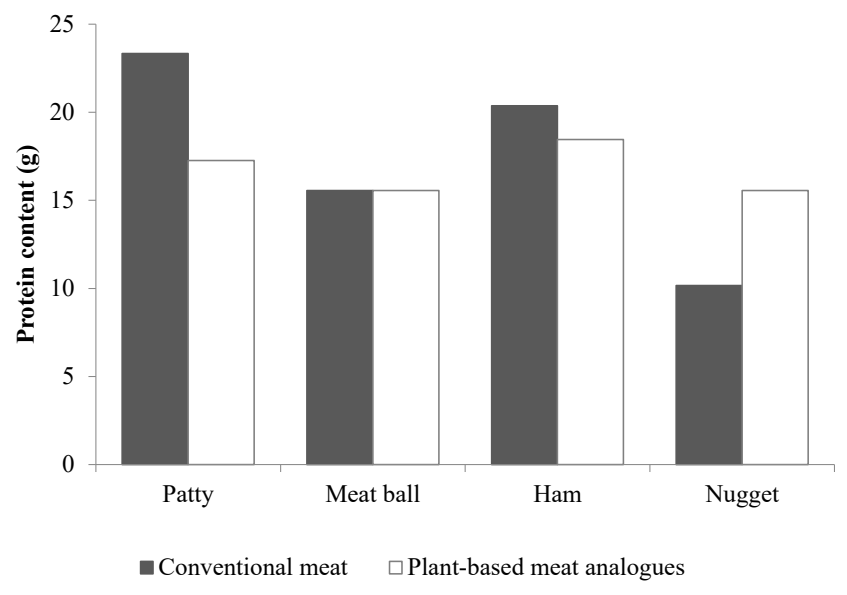

Figure 1. Protein content $(\mathrm{g})$ in four different types of traditional meat and plant-based meat analogues in market. Modified from Bohrer [14].

\section{Research trends and challenges}

Despite the good nutritional value and continuous development of plant-based meat analogues, their palatability remains a critical obstacle for consumer acceptability. For improving the texture and flavor of plant-based meat analogues, different ingredients are added during the manufacturing process (Table 3). Regarding texture, different techniques such as spinning, thermoplastic extrusion, and steam texturization have also been applied for the structural organization of plant protein, as plants are mainly composed of amorphous tissue

Table 3. Ingredient used during the manufacture of plant-based meat analogues

\begin{tabular}{|c|c|c|}
\hline Ingredient & Purpose & Usage level (\%) \\
\hline Water & $\begin{array}{l}\cdot \text { Ingredient distribution } \\
\cdot \text { Emulsification, juiciness, cost }\end{array}$ & $50-80$ \\
\hline Textured vegetable proteins & $\begin{array}{l}\text {-Water binding, Texture/mouthfeel } \\
\text { - Appearance; protein fortification/nutrition } \\
\text { - Source of insoluble fiber }\end{array}$ & $10-25$ \\
\hline Non-textured proteins & $\begin{array}{l}\text { - Water binding, emulsification } \\
\text { - Texture/mouthfeel } \\
\text { - Protein fortification/nutrition }\end{array}$ & $4-20$ \\
\hline Flavors/spices & $\begin{array}{l}\text { - Flavor: savory, meaty, roasted, fatty, serumy } \\
\text { - Flavor enhancement (for example, salt) } \\
\text { - Mask cereal notes }\end{array}$ & $3-10$ \\
\hline Fat/oil & $\begin{array}{l}\text { · Flavor, texture/mouthfeel } \\
\text { · Succulence, Maillard reaction/browning }\end{array}$ & $0-15$ \\
\hline Binding agents & $\begin{array}{l}\text { - Texture/"bite," water binding, may contribute to fiber content, } \\
\text { can determine production processing conditions }\end{array}$ & $1-5$ \\
\hline Coloring agents & $\begin{array}{l}\text { - Appearance/eye appeal } \\
\text { - Natural or artificial }\end{array}$ & $0-0.5$ \\
\hline
\end{tabular}

Adapted from Asgar et al [13]. 
[20,21]. Among these, extrusion is the most frequently used technique, as it is an economical method and can manufacture different shapes and sizes of meat analogues. The process is based on a screw system within a barrel [22] by means of which plant proteins are compressed, heated to be restructured into a striated, layered, and cross-linked mass, ultimately leading to the production of TVP $[13,23]$. Previous research suggested that utilizing wheat gluten and soybean protein as TVP ingredients could impart an appearance, texture, taste, and nutritional value similar to that of traditional meat [24]. In addition, proteins produced from starch by-products using fungi (a.k.a. mycoprotein) have structures and diameters similar to those of muscle fibers of meat with almost a similar texture $[13,21]$.

The flavor of traditional meat is mainly derived from flavorrelated compounds such as free amino acids, free fatty acids, nucleotides, and reducing sugars. Besides, vitamin B1 and myoglobin also affect the flavor of meat [25]. Therefore, when plant-based meat analogues are produced, flavor enhancers are added (Table 3). According to Kyriakopoulou et al [26], when volatile compounds in traditional meat are isolated after a combination of various thermal processes, a flavor concentrate of meat is obtained. Subsequently, different techniques have been investigated and developed to incorporate such flavor concentrates into plant-based meat analogues to achieve a meat flavor. Addition of fat/oil (e.g., canola oil, coconut oil, and sunflower oil) can also affect the formation of flavor in plant-based meat analogues as well as their texture and mouthfeel $[13,14]$.

Another challenge for plant-based meat analogues is the appearance, especially color. The color of meat and meat analogues is an important attribute at the point of purchase in the market [27]. To represent the color of red meat, some meat analogue products contain beet juice extract or tomato paste [14]. However, meat color does not always appear red, and it changes depending on the chemical state of myoglobin, which is primarily responsible for the meat color. Despite fresh meat possessing a bright red color due to high oxymyoglobin content, the meat color changes to brown, and metmyoglobin content increases when meat is cooked [28]. Some researchers have proposed that meat analogues should have color attributes similar to those of traditional raw or cooked meat [26]. Thus, the meat industry produces and uses leghemoglobin, which has a similar chemical state and structure as myoglobin. A representative product containing leghemoglobin is the Impossible Burger (Impossible Foods Inc., Redwood City, CA, USA). When leghemoglobin is added to a meat analogue product, it imparts cooked-color characteristics similar to those of traditional meat [14,29]. Myoglobin also affects meat flavor. Thus, Fraser et al [30] reported that the use of leghemoglobin, which is similar to myoglobin, provided a distinct meat flavor to meat analogues. In addition, leghemoglobin was shown to be free of toxicity as examined by in vitro chromosomal aberration tests and in vivo systemic toxicity test [30].

As plant protein and food-grade ingredients are mainly used during manufacture of plant-based meat analogues, their safety is approved, and production cost is feasible [31]. However, several anti-nutrients (e.g., protease inhibitors, $\alpha$-amylase inhibitors, lectin, polyphenols, and phytic acid) are present in plant-based meat analogues. Although these compounds are known for their positive effects, such as anticarcinogenic, anti-obesity, lymphocyte stimulation, antioxidant effects, and others, their negative effects have also been reported [13]. For example, polyphenols can decrease the activities of digestive enzymes as well as bioavailability of proteins and amino acids. Phytic acid can induce mineral depletion and micronutrient deficiency as it reduces the bioavailability of essential minerals and binds micronutrients (e.g., $\mathrm{Fe}, \mathrm{Zn}, \mathrm{K}, \mathrm{Cu}, \mathrm{Co}, \mathrm{Mg}$, and $\mathrm{Ca}$ ). Furthermore, food allergies to plant protein need to be addressed, since plant proteins, especially legume proteins themselves contain some allergens.

Interestingly, when compared with natural beef, plantbased meat analogues have more energy value, total fats, saturated fats, and $\mathrm{Na}$ and $\mathrm{Fe}$ contents [14], perhaps because of the addition of excess fat and/or oil (e.g., coconut oil and cocoa butter) for mimicking animal fat, coloring agents, and spices to the meat analogues during the processing of plant proteins (Table 3). These results reveal that manufacture of plant-based meat analogues may reduce the benefits of nutrients present in the original plant protein itself. In the absence of such a processing step, fat and saturated fat contents of plant protein varied from 0.5 to 8 and 0 to $0.9 \mathrm{~g} / 100 \mathrm{~g}$, respectively [32]. Nevertheless, the challenges can be overcome by advanced technological development, and plant-based meat analogues will be important protein sources in the future.

\section{Edible insects}

Definition and present features: Insects are one of the largest living resources on the earth, with a total of 5.5 million species [33]. Among them, almost 2,000 species of insects are consumed in 113 countries, especially Africa, South America, and Southeast Asia $[34,35]$. In such regions, eating insects is an ancient custom (so-called entomophagy) from at least 3,000 years ago. Insects have been used as a valuable protein resource for their high protein content with essential amino acids sufficient for our daily requirement [36-38]. The most frequently consumed species of insects are coleoptera (beetles), lepidoptera (caterpillars), hymenoptera (ants, wasps, and bees), orthoptera (locusts, grasshoppers, and crickets), hemiptera (leafhoppers, planthoppers, and cicadas), isoptera (termites), odonata (dragonflies), and diptera (flies) [39,40].

However, the acceptance of eating insects is low in western consumers, mostly because of a negative image regarding 
insects, especially as a food component. Therefore, entomophagy has decreased in our diet, as various food product options are increasingly available with the development of food science and technology $[36,37,41]$. Consequently, there is an urgent need for meat alternatives due to the importance of traditional meat as a main diet in our lives [42]. Nonetheless, the importance of edible insects has emerged because of the increasing need for meat alternatives for proteins. In recent years, the market for insects is steadily increasing and is expected to exceed $\$ 522$ million US dollars by 2023 [43].

\section{Benefits as meat alternatives}

The major purpose of the consumption of insects by humans is to provide an excellent source of proteins. The nutritional values of edible insects vary depending on their species, sex, metamorphosis state (e.g., larvae, pupae, and adults), origin, diet, and different methods of processing due to their large diversities (Table 4) [35,44]. Xiaoming et al [45] reported that protein content in 100 different species ranged from $13 \%$ to $77 \%$ on the basis of their dry matter. Analyses of 87 insect species in Mexico revealed a protein content of $15 \%$ to $81 \%$ with high digestibility [46]. de Castro et al [44] reviewed the nutritional value of frequently consumed insects (e.g., beetles, files, bugs, bees, wasps, sawflies and ants, butterflies and moths, grasshoppers, crickets, and locusts) and found large variations ( $1 \%$ to $81 \%)$ among the protein contents. The bioavailability of insect protein is also high with good digestibility ( $76 \%$ to $96 \%$ ), which is a little less than that of egg or beef protein (95\% and $98 \%$, respectively) [35,47]. Thus, undoubtedly, insects can serve as a fine protein source in our diet. In Central Africa, there was a time when about $50 \%$ of dietary proteins were obtained from insects [42]. Compared to plant protein, insect protein has nutritional benefits with respect to total protein levels, essential amino acids, and bioavailability. Kouřimská and Adámková [35] stated that some species of insects have high lysine, tryptophan, and threonine contents, which are not found in some plants.

Edible insects can provide other beneficial nutrients such as fats with highly unsaturated fatty acids, vitamins, and minerals $[35,44]$. In insects, fat is the second abundant nutrient (approximately 10\% to 60\%, on the basis of dry matter) followed by proteins. In general, the fats can be classified into $80 \%$ triglycerides and $20 \%$ phospholipids, which play a role in energy reserves, cell membrane structure, and regulatory physiology $[35,48]$. The profile of unsaturated fatty acids in edible insects is comparable to that of poultry and fish; however, insects have more polyunsaturated fatty acids $[42,49]$. Rumpold and Schlüter [49] reported that major omega-3 fatty acids, including eicosapentaenoic acid and docosahexaenoic acid, were not detected in most insects; however, their levels could be increased with feed modifications during insect rearing. In addition, edible insects are rich in $\mathrm{Fe}, \mathrm{Zn}, \mathrm{Na}$, $\mathrm{Ca}, \mathrm{P}, \mathrm{Mg}, \mathrm{Mn}, \mathrm{Cu}$, riboflavin, pantothenic acid, and biotin $[49,50]$.

The benefits of edible insects are not only limited to their high nutritional content, but also to high feed/meat conversion rate and lower requirements of land, water, and feed $[44,51,52]$. In addition, they have a high fecundity rate with year-round breeding and small space requirements. In some species (e.g., palm weevil larvae), the byproducts can be used for other livestock and/or humans, resulting in high recycling capability.

\section{Research trends and challenges}

Many studies have been conducted on the use of edible insects as human food or ingredients. However, despite constant efforts to expand their market and consumption, eating insects may not become a mainstream dining option [43]. People are hesitant to consume insects owing to a skeptical attitude towards novel foods [42,52]; This is a part of food neophobia, which can determine the acceptance of edible insects as meat alternatives [53]. Consumers who have not experienced consuming edible insects perceive insects to be dirty, disgusting, and dangerous, ultimately rejecting them as a food resource [54]. This phenomenon is a main challenge for consumption of edible insects, especially in Western coun-

Table 4. Nutrient composition of edible insects depending on different species (on a dry matter basis)

\begin{tabular}{|c|c|c|c|c|c|c|}
\hline Edible insects & Protein (\%) & Fat $(\%)$ & Fiber (\%) & NFE (\%) & Ash (\%) & $\begin{array}{l}\text { Energy content } \\
\text { (Kcal/100 g) }\end{array}$ \\
\hline Blattodea (cockroaches) & 57.30 & 29.90 & 5.31 & 4.53 & 2.94 & - \\
\hline Coleoptera (beetles, grubs) & 40.69 & 33.40 & 10.74 & 13.20 & 5.07 & 490.30 \\
\hline Diptera (flies) & 49.48 & 22.75 & 13.56 & 6.01 & 10.31 & 409.78 \\
\hline Hemiptera (true bugs) & 48.33 & 30.26 & 12.40 & 6.08 & 5.03 & 478.99 \\
\hline Hymenoptera (ants, bees) & 46.47 & 25.09 & 5.71 & 20.25 & 3.51 & 484.45 \\
\hline Isoptera (termites) & 35.34 & 32.74 & 5.06 & 22.84 & 5.88 & - \\
\hline Lepidoptera (butterflies, moths) & 45.38 & 27.66 & 6.60 & 18.76 & 4.51 & 508.89 \\
\hline Odonata (dragonflies, damselflies) & 55.23 & 19.83 & 11.79 & 4.63 & 8.53 & 431.33 \\
\hline Orthoptera (crickets, grasshoppers, locusts) & 61.32 & 13.41 & 9.55 & 12.98 & 3.85 & 426.25 \\
\hline
\end{tabular}

Modified from Rumpold and Schlüter [49]. 
tries [43]. According to Verbeke [55], only a few consumers (12.8\% males and $6.3 \%$ females) in the Western society accept edible insects as a food item. Post [56] also reported that most of the insects in the Netherlands are used as a pet food rather than human diet. To overcome food neophobia related to insects, regular inclusion of insects in the daily diet can be helpful, while increasing its positive perception [44,52]. Imparting information on the benefits of edible insects on the aspects of nutrition, environment, and culture is considered another solution [51,57]. However, its actual effect is still negligible, and the Western civilization is not ready to eat edible insects in intact forms [52].

The development of insect-based ingredients/products rather than intact forms can facilitate the adoption of insects as a food resource [57-59]. Therefore, several studies have been conducted to process insects as new food ingredients and to include them in familiar foods or in processing of food products [36,37]. These methods involve raw material processing, protein processing, and oil processing [53], which can improve the quality characteristics (e.g., flavor) and functional properties (e.g., angiotensin I converting enzyme inhibitory activity and antimicrobial and antioxidant functions) when applied to food ingredients $[44,60]$. Recently, raw material processing through drying and/or milling is the most widely used method for applying edible insects as a food product. When insects are converted to a dry powder, their volume is lower than that of the original product, resulting in easier transportation; in addition, the product can be stored for a long time owing to low water activity. Meanwhile, protein and oil-processing methods have been investigated to extract proteins and oils from insects. These extracting processing not only enhance nutritional values but also increase technical functional properties [37]. Various edible insects are added as ingredients to foods such as bread, cookies, and sausages to enhance their nutritional value and food quality. Therefore, insects can be used without their negative image impact to enhance the aforementioned properties of food products [52].

Nonetheless, safety issues of edible insects, such as antinutrients (e.g., chitin and toxic substances [cryptotoxics and phanerotoxics]), microbial risk, and allergens, still exist [42, 44]. Sufficient data to confirm the safety of anti-nutrients in insects should be obtained in future studies. In particular, since studies on food allergies of insects are limited, further investigations are needed for the growth of the edible insect industry [39]. Till date, some allergic cross-reactive proteins of arthropods (arachnids and crustaceans) are known [61].

\section{Cultured meat}

Definition and present features: Cultured meat (also called in vitro meat, synthetic meat, lab-grown meat, bioartificial muscle, and Frankenstein meat) is the latest emerging meat alternative. It can be defined as artificial meat produced using stem cell technology [62]. The idea of cultured meat was first mentioned in 1932 by Winston Churchill, a previous prime minister of UK. Cell and tissue engineering techniques have been developed for medical purposes. However, recently, because of advanced technological inputs, they have been applied in the field of food technology $[63,64]$ for large-scale culturing [56]. Based on such developments, the first beef patty cultured from bovine muscle cell was introduced to the public in 2013. The patty was made of muscle cells with the addition of beet juice and saffron to make a meat-like product; however, production cost was extremely high [63, 65].

So far, cultured meat could not be commercialized owing to technical difficulties in its mass production and cost. The patty (approximately $85 \mathrm{~g}$ ) made by Dr. Post required US $\$ 330,000$ in 2013, and a meatball (approximately $1 \mathrm{~kg}$ ), which was recently unveiled by Memphis Meat, cost US $\$ 40,000$ [63, 65]. Therefore, to launch cultured meat in the market, its production cost should be lowered, and quality characteristics should be improved. The optimization process should be preceded by the whole process of cultured meat [66]. Once cultured meat is produced with a similar quality to that of traditional meat, it may play an important role in increasing meat supplies because it will be the only actual meat that has animal protein $[67,68]$. Mosameat, Memphis Meats, Super Meat, Integriculture, Just, and others are major companies manufacturing cultured meat; they are planning to release their products from 2021. Various types of cultured meat, such as meatballs, burgers, and sausages may be launched, and their market size is expected to be US $\$ 4.3$ million for meatballs, US \$3.7 million for burgers, and US \$3.3 million for sausages. One of the articles reported that the appearance of cultured meat is expected to change the trends in global meat market, as it is expected to occupy $35 \%$ of the global meat market in the next 20 years [69].

\section{Benefits as meat alternatives}

The biggest merits of cultured meat are its similarities to traditional meat, as it is derived from farm animals, and may be environmentally sustainable $[67,68]$. This product can meet both the nutritional and sensory preferences of consumers because of its superior taste and texture than other meat alternatives [62]. In this respect, cultured meat can attract consumers who do not want to change their traditional diet style of meat consumption. Besides, according to Zhang et al [68], during the production of cultured meat, a single cell can proliferate several times; therefore, fewer numbers of animals are needed than in livestock farming.

In addition, there are other advantages of cultured meat. Bhat et al [63] suggested that cultured meat may be utilized for several other applications, such as creation of functional and designer meat, quick production, availability of exotic 
meat, vegan meat, efficient nutrient, and energy conversion. Besides, the benefits of cultured meat include public support, animal welfare, reduction in zoonotic and food borne disease, reduction in resource use and ecological foot print, and reforestation and wild life protection; it can also be used for space missions and settlements. Although the development of cultured meat is still in progress, it may be possible to control the ingredients in the products to have more health benefits without long farming processes [63]. In addition, all processes in culturing meat are conducted under sterile conditions employing various food quality and safety management systems such as Good Manufacturing Practice and Hazard Analysis and Critical Control Points. Therefore, it is possible to produce safer products devoid of hazards such as contamination, antibiotic abuse, infectious diseases, and food poisoning [68].

\section{Research trends and challenges}

Although cultured meat is about to be released in a few years, technologies for its processing are still insufficient. The most urgent challenge could possibly be the development and optimization of mass production process with reasonable pricing. From the choice of cells to tissue engineering techniques (Table 5) (See Specht et al [70] for more detailed information), uncertainties in cell culture and muscle development should be studied and further optimized for the mass production of cultured meat $[63,65]$. Gaydhane et al $[71]$ suggested cells, culture media, scaffolds, bioreactors, culture conditions, and processing (also called mimicking) as the key factors for producing cultured meat; this report mostly agrees with other studies $[68,72-74]$. As the range of studies conducted on such factors is quite wide and comprehensive details are not yet clear, only a brief introduction on the culture media, scaffolds, and bioreactors will be discussed in this review based on the currently-available literatures.

During cell culture, optimal formulation of culture media is important, as it can affect growth rate of cells [71]. Culture media contain various nutrients, hormones, sera with growth factors, and other components for cell growth [73]. Among them, the use of serum (e.g., fetal bovine serum, horse serum) in culture media is a cause for concern. Serum is a necessary component in culture media, as it can facilitate the growth of muscle satellite cells. However, researchers have suggested that its use in culture media should be replaced or eliminated, as it is variable and expensive and is a main reason of high production cost of cultured meat [67]. In addition, its production process may not be ethical and sustainable, as it is derived from calves. Therefore, alternative ingredients for serum in culture media, especially serum-free media, have been one of the main research areas for cultured meat.

Bioreactor and scaffolds are other important factors in

Table 5. Critical technology elements of cultured meat

\begin{tabular}{|c|c|c|}
\hline $\begin{array}{l}\text { Critical technology } \\
\text { elements }\end{array}$ & Design requirements for cultured meat & $\begin{array}{l}\text { Relevant technologies and advances within } \\
\text { the cell-based therapeutics industry }\end{array}$ \\
\hline Cell line & $\begin{array}{l}\text { - Derived from agriculturally-relevant species } \\
\text { - Capable of differentiation into meat-relevant cell types (muscle, fat, } \\
\text { fibroblast, etc.) } \\
\text { - Genetically stable and immortalized } \\
\text { - Optimized for large-scale growth (tolerate suspension, controlled } \\
\text { differentiation, etc.) }\end{array}$ & $\begin{array}{l}\text { - Development of small molecule cocktails that can replace } \\
\text { the need for genetic approaches to induce pluripotency and } \\
\text { to facilitate maintenance of pluripotency } \\
\text { - Footprint-free methods of cell line engineering using RNA or } \\
\text { protein delivery or excisable transposons } \\
\text { - Improved protocols for cell freezing to maintain viability and } \\
\text { phenotypic fidelity }\end{array}$ \\
\hline Culture media & $\begin{array}{l}\text { - Animal component-free, antibiotic-free, ideally chemically defined } \\
\text { - Optimized for meat-relevant cell lines and co-culture of multiple cell types } \\
\text { - Extremely low cost and high-volume production capacity } \\
\text { - Engineered or synthetic growth factors }\end{array}$ & $\begin{array}{l}\text { - Development of methods for streamlining iterative optimiza- } \\
\text { tion of animal component-free media formulations } \\
\text { - Immobilizing growth factors on beads to prevent depletion } \\
\text { in the media via perfusion }\end{array}$ \\
\hline Scaffolding & $\begin{array}{l}\text { - Edible and/or biodegradable and food grade materials } \\
\text { - Support cell adherence } \\
\text { - Support vascularization and media perfusion } \\
\text { - Biomechanical properties suitable for tissue maturation } \\
\text { - Scalable production capacity }\end{array}$ & $\begin{array}{l}\text { - Biocompatible, non-animal-derived scaffolding materials } \\
\text { pioneered in the regenerative medicine field } \\
\text { - Use of tunable scaffold parameters (stiffness, etc.) to spatial- } \\
\text { ly direct differentiation } \\
\text { - Degradable materials that enable cell migration and vascu- } \\
\text { larization after patient implantation }\end{array}$ \\
\hline Bioreactors & $\begin{array}{l}\text { - Support cell proliferation as well as tissue maturation/perfusion } \\
\text { - Large volume, low maintenance } \\
\text { - High-yield cell harvesting } \\
\text { - Real-time, in-line cell monitoring for quality control } \\
\text { - Integrated media filtration and recycling system } \\
\text { - Highly automated; closed system }\end{array}$ & $\begin{array}{l}\text { - Integrated, closed systems with increasing automation to } \\
\text { reduce errors and contamination risk associated with human } \\
\text { handling } \\
\text { - In-line monitoring of media components to adjust perfusion } \\
\text { in real time } \\
\text { - Novel technologies to improve efficiency of cell separation } \\
\text { and harvesting }\end{array}$ \\
\hline
\end{tabular}

Adapted from Specht et al [70]. 


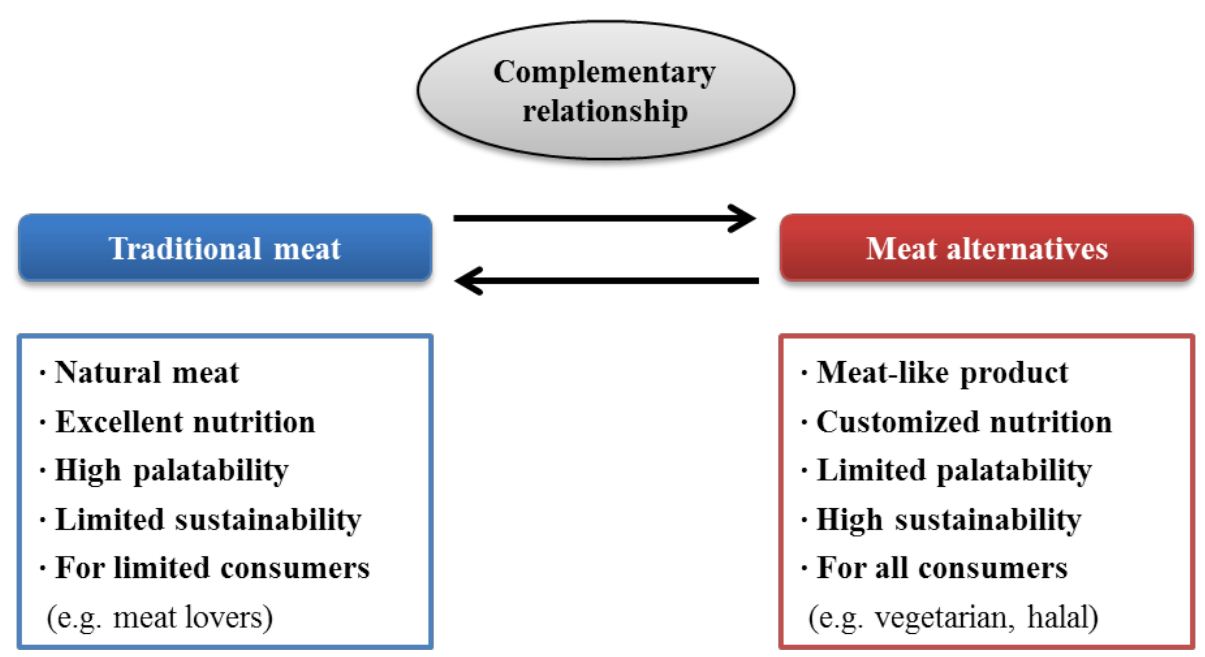

Figure 2. Final goal of traditional meat and meat alternatives in the future.

mass production of cultured meat [75]. In general, a bioreactor is applied for large-scale cell growth under controlled conditions of temperature, $\mathrm{pH}$, oxygen partial pressure, and shear stress, providing a more homogeneous environment during cell proliferation and/or differentiation with detailed monitoring of its conditions [76,77]. Previous studies have reported that different types and conditions of bioreactors can affect mass production of cultured meat. In the last few years, various types of bioreactors (e.g., stirred tank bioreactor [a.k.a. spinner flask], High-Aspect-Ratio-Vessel bioreactor, fluidized bed bioreactor, hollow fiber bioreactors, and packed bed bioreactors) have been developed with different sizes [76,78]. Moreover, not only temperature and $\mathrm{pH}$, but also oxygen partial pressure and shear stress are important for optimal conditions of a bioreactor. For example, low oxygen partial pressure decreases the differentiation rate of cells, but increases their proliferation. In the case of shear stress, its application with increasing impeller size and rpm as well as its location and the internal vessel used can affect cell damage. Therefore, low shear stress and stable oxygen perfusion should be set up in a bioreactor even at large volumes [72]. Furthermore, efficiencies of bioreactors varied for different cell lines. Therefore, customized bioreactors and their proper use should be investigated for optimization of mass production of cultured meat.

Scaffolding is a method that can impart more meat-like texture to cultured meat instead of complex co-culture of connective tissue [79]. Scaffolds consist of biopolymers, and their application is known to be best suited for cultured meat. Cell-attached scaffolds are suspended in a bioreactor with culture media, producing cultured meat on a large-scale $[64,68]$. When considering the requirements for scaffolds, collagen is the most frequently used material, and plant-based sources (e.g., alginate, cellulose, or chitosan) have also been developed
[79]. However, so far, scaffolding cannot be used to prepare a highly-structured product and is only capable of producing ground and/or emulsified products; therefore, improvement of a highly-developed structure of cultured meat is one of the challenges in future $[63,72]$.

\section{CONCLUSION}

There is no doubt that livestock-based traditional meat and meat products are the best protein sources, with excellent palatability and ample consumption. However, changes in consumers' perception and the value of land/water resources and environmental sustainability will lead to the development of meat alternatives. Consequently, to conserve the limited supply of traditional meat, meat alternatives, including plant-based meat analogues, edible insects, and cultured meat, will play important roles, depending on the degree of their technical development and consumer acceptance, while maintaining a complementary relationship with traditional meat (Figure 2).

\section{CONFLICT OF INTEREST}

We certify that there is no conflict of interest with any financial organization regarding the material discussed in the manuscript.

\section{ACKNOWLEDGMENTS}

This study was supported by "High Value-added Food Technology Development Program (Project No. 118042-03)", Korea Institute of Planning and Evaluation for Technology in Food, Agriculture, Forestry and Fisheries and the BK21 Plus Program of the Department of Agricultural Biotechnology, Seoul 
National University, Seoul, Korea.

\section{REFERENCES}

1. Alexander P, Brown C, Arneth A, et al. Could consumption of insects, cultured meat or imitation meat reduce global agricultural land use? Glob Food Sec 2017;15:22-32. https:// doi.org/10.1016/j.gfs.2017.04.001

2. Fiddes, N. Meat: A natural symbol. 1st ed. New York, USA: Routledge; 2004.

3. Pereira PMDCC, Vicente AFDRB. Meat nutritional composition and nutritive role in the human diet. Meat Sci 2013;93: 586-92. https://doi.org/10.1016/j.meatsci.2012.09.018

4. Elmadfa I, Meyer AL. Animal proteins as important contributors to a healthy human diet. Annu Rev Anim Biosci 2017; 5:111-31. https://doi.org/10.1146/annurev-animal-022516022943

5. de Smet S, Vossen E. Meat: The balance between nutrition and health. A review. Meat Sci 2016;120:145-56. https:/doi. org/10.1016/j.meatsci.2016.04.008

6. Williams P. Nutritional composition of red meat. Nutr Diet 2007;64:S113-9. https://doi.org/10.1111/j.1747-0080.2007. 00197.x

7. Font-i-Furnols M, Guerrero L. Consumer preference, behavior and perception about meat and meat products: an overview. Meat Sci 2014;98:361-71. https://doi.org/10.1016/j.meatsci. 2014.06.025

8. Leroy F, Praet I. Meat traditions. The co-evolution of humans and meat. Appetite 2015;90:200-11. https://doi.org/10.1016/ j.appet.2015.03.014

9. Seleshe S, Jo C, Lee M. Meat consumption culture in Ethiopia. Korean J Food Sci An 2014;34:7-13. https://doi.org/10.5851/ kosfa.2014.34.1.7

10. Bonny SPF, Gardner GE, Pethick DW, Hocquette JF. What is artificial meat and what does it mean for the future of the meat industry? J Integr Agric 2015;14:255-63. https://doi.org/ 10.1016/S2095-3119(14)60888-1

11. Bryant C, Barnett J. Consumer acceptance of cultured meat: a systematic review. Meat sci 2018;143:8-17. https://doi.org/ 10.1016/j.meatsci.2018.04.008

12. Nam KC, Jo C, Lee M. Meat products and consumption culture in the East. Meat Sci 2010;86:95-102. https://doi.org/10.1016/ j.meatsci.2010.04.026

13. Asgar MA, Fazilah A, Huda N, Bhat R, Karim AA. Nonmeat protein alternatives as meat extenders and meat analogs. Compr Rev Food Sci Food Saf 2010;9:513-29. https://doi.org/10.1111/ j.1541-4337.2010.00124.x

14. Bohrer BM. An investigation of the formulation and nutritional composition of modern meat analogue products. Food Sci Hum Wellness 2019;8:320-9. https://doi.org/10.1016/j. fshw.2019.11.006

15.Shurtleff W, Aoyagi A. History of meat alternatives (965 CE to 2014). 1st ed. Lafayette CA, USA: Soyinfo Center; 2014.

16. Joshi VK, Kumar S. Meat Analogues: Plant based alternatives to meat products-a review. Int J Food Ferment Technol 2015; 5:107-19. https://doi.org/10.5958/2277-9396.2016.00001.5

17. Tabe L, Higgins TJV. Engineering plant protein composition for improved nutrition. Trends Plant Sci 1998;3:282-6. https:// doi.org/10.1016/S1360-1385(98)01267-9

18. Malav OP, Talukder S, Gokulakrishnan P, Chand S. Meat analog: a review. Crit Rev Food Sci Nutr 2015;55:1241-5. https://doi. org/10.1080/10408398.2012.689381

19.Liu X, Zhang X, Zhu C, Wang J. Nutrition and health function of soybean drawing protein and its application in food. In: Proceedings of the 2017 6th International Conference on Energy, Environment and Sustainable Development; 2017 Mar 11-12; Zhuhai, China: Atlantis Press; 2017. pp. 581.

20.Dekkers BL, Boom RM, van der Goot AJ. Structuring processes for meat analogues. Trends Food Sci Technol 2018; 81:25-36. https://doi.org/10.1016/j.tifs.2018.08.011

21.Kim CJ. Development of meat substitutes using vegetable protein. In: Proceedings of the EASDL Conference 2005; 2005 Apr 30; Chonan, Korea: The East Asian Society of Dietary Life; 2005. pp. 75.

22.Tziva M, Negro SO, Kalfagianni A, Hekkert MP. Understanding the protein transition: the rise of plant-based meat substitutes. Environ Innov Soc Transit 2020;35:217-31. https://doi.org/ 10.1016/j.eist.2019.09.004

23. Alam MS, Kaur J, Khaira H, Gupta K. Extrusion and extruded products: changes in quality attributes as affected by extrusion process parameters: a review. Crit Rev Food Sci Nutr 2016;56: 445-73. https://doi.org/10.1080/10408398.2013.779568

24. Samard S, Ryu GH. A comparison of physicochemical characteristics, texture, and structure of meat analogue and meats. J Sci Food Agric 2019;99:2708-15. https://doi.org/10.1002/ jsfa.9438

25. Mottram DS. Flavour formation in meat and meat products: a review. Food Chem 1998;62:415-24. https://doi.org/10.1016/ S0308-8146(98)00076-4

26. Kyriakopoulou K, Dekkers B, van der Goot AJ. Plant-based meat analogues. In: CM Galanakis, editors. London UK: Sustainable Meat Production and Processing Academic Press; 2019. p. 103-26. https://doi.org/10.1016/B978-0-12-814874-7. 00006-7

27.Troy DJ, Kerry JP. Consumer perception and the role of science in the meat industry. Meat Sci 2010;86:214-26. https://doi.org/ 10.1016/j.meatsci.2010.05.009

28. Suman SP, Joseph P. Myoglobin chemistry and meat color. Annu Rev Food Sci Technol 2013;4:79-99. https://doi.org/10. 1146/annurev-food-030212-182623

29. Goldstein B, Moses R, Sammons N, Birkved M. Potential to curb the environmental burdens of American beef consumption using a novel plant-based beef substitute. PloS one 2017; 12:e0189029. https://doi.org/10.1371/journal.pone.0189029 
30. Fraser RZ, Shitut M, Agrawal P, Mendes O, Klapholz S. Safety evaluation of soy leghemoglobin protein preparation derived from Pichia pastoris, intended for use as a flavor catalyst in plant-based meat. Int J Toxicol 2018;37:241-62. https://doi. org/10.1177/1091581818766318

31.Jeong JY, Jo C. Utilization of meat substitutes and materials in the meat and meat processing industry. Food Sci Anim Resour Ind 2018;7:2-11.

32. Sadler MJ. Meat alternatives - market developments and health benefits. Trends Food Sci Technol 2004;15:250-60. https:// doi.org/10.1016/j.tifs.2003.09.003

33. Stork NE. How many species of insects and other terrestrial arthropods are there on Earth? Annu Rev Entomol 2018; 63:31-45. https://doi.org/10.1146/annurev-ento-020117-043348

34. de Carvalho NM, Madureira AR, Pintado ME. The potential of insects as food sources-a review. Crit Rev Food Sci Nutr 2019 Dec 23 [Epub]. https://doi.org/10.1080/10408398.201 9.1703170

35. Kouřimská L, Adámková A. Nutritional and sensory quality of edible insects. NFS J 2016;4:22-6. https://doi.org/10.1016/j. nfs.2016.07.001

36. Kim TK, Yong HI, Jeong $\mathrm{CH}$, et al. Technical functional properties of water- and salt-soluble proteins extracted from edible insects. Food Sci Anim Resour 2019;39:643-54. https://doi. org/10.5851/kosfa.2019.e56

37. Kim TK, Yong HI, Kim YB, Kim HW, Choi YS. Edible insects as a protein source: a review of public perception, processing technology, and research trends. Food Sci Anim Resour 2019; 39:521-40. https://doi.org/10.5851/kosfa.2019.e53

38. Pippinato L, Gasco L, Di Vita G, Mancuso T. Current scenario in the European edible-insect industry: a preliminary study. J Insects Food Feed 2020 Apr 17 [Epub]. https://doi.org/10. 3920/JIFF2020.0008

39. de Gier S, Verhoeckx K. Insect (food) allergy and allergens. Mol Immunol 2018;100:82-106. https://doi.org/10.1016/j. molimm.2018.03.015

40. Jongema Y. List of edible insects of the world [internet]. Wageningen University Research; c2017. [Cited 2020 Jun 5]. Available from: https://www.wur.nl/en/Research-Results/ Chair-groups/Plant-Sciences/Laboratory-of-Entomology/ Edible-insects/Worldwide-species-list.htm

41. Looy H, Dunkel FV, Wood JR. How then shall we eat? Insecteating attitudes and sustainable foodways. Agric Hum Values 2014;31:131-41. https://doi.org/10.1007/s10460-013-9450-X

42. Dobermann D, Swift JA, Field LM. Opportunities and hurdles of edible insects for food and feed. Nutr Bull 2017;42:293308. https://doi.org/10.1111/nbu.12291

43. van Thielen L, Vermuyten S, Storms B, Rumpold B, Van Campenhout L. Consumer acceptance of foods containing edible insects in Belgium two years after their introduction to the market. J Insects Food Feed 2019;5:35-44. https://doi.org/10. 3920/JIFF2017.0075 44.de Castro RJS, Ohara A, dos Santos Aguilar JG, Domingues MAF. Nutritional, functional and biological properties of insect proteins: Processes for obtaining, consumption and future challenges. Trends Food Sci Technol 2018;76:82-9. https://doi.org/10.1016/j.tifs.2018.04.006

45.Xiaoming C, Ying F, Hong Z, Zhiyong C. Review of the nutritive value of edible insects. In: Proceedings of a Workshop on Asia-Pacific Resources and their Potential for Development 2010; 2010 Feb 19-Feb 21. Bangkok, Thailand. pp. 85.

46. Ramos-Elorduy J, Moreno JMP, Prado EE, Perez MA, Otero JL, de Guevara OL. Nutritional value of edible insects from the state of Oaxaca, Mexico. J Food Compost Anal 1997;10: 142-57. https://doi.org/10.1006/jfca.1997.0530

47. Bukkens SG. The nutritional value of edible insects. Ecol Food Nutr 1997;36:287-319. https://doi.org/10.1080/03670244.19 97.9991521

48. Stanley-Samuelson DW, Jurenka RA, Cripps C, Blomquist GJ, de Renobales M. Fatty acids in insects: composition, metabolism, and biological significance. Arch Insect Biochem Physiol 1988;9:1-33. https://doi.org/10.1002/arch.940090102

49. Rumpold BA, Schlüter OK. Potential and challenges of insects as an innovative source for food and feed production. Innov Food Sci Emerg Technol 2013;17:1-11. https://doi.org/10.1016/ j.ifset.2012.11.005

50. Mlcek J, Rop O, Borkovcova M, Bednarova M. A comprehensive look at the possibilities of edible insects as food in Europe - a review. Pol J Food Nutr Sci 2014;64:147-57. https://doi. org/10.2478/v10222-012-0099-8

51. Ghosh S, Lee SM, Jung C, Meyer-Rochow VB. Nutritional composition of five commercial edible insects in South Korea. J Asia-Pac Entomol 2017;20:686-94. https://doi.org/10.1016/ j.aspen.2017.04.003

52. Megido RC, Gierts C, Blecker C, et al. Consumer acceptance of insect-based alternative meat products in Western countries. Food Qual Prefer 2016;52:237-43. https://doi.org/10.1016/ j.foodqual.2016.05.004

53. Sosa DAT. Fogliano V. Potential of insect-derived ingredients for food applications. In: Shields VDC, editors. Insect physiology and ecology. Rijeka, Croatia: IntechOpen; 2017. p. 215-31. https://doi.org/10.5772/67318

54.van Huis A. Potential of insects as food and feed in assuring food security. Annu Rev Entomol 2013;58:563-83. https://doi. org/10.1146/annurev-ento-120811-153704

55 . Verbeke W. Profiling consumers who are ready to adopt insects as a meat substitute in a Western society. Food Qual Prefer 2015;39:147-55. https://doi.org/10.1016/j.foodqual. 2014.07. 008

56. Post MJ. Cultured beef: medical technology to produce food. J Sci Food Agric 2014;94:1039-41. https://doi.org/10.1002/ jsfa.6474

57.Han R, Shin JT, Kim J, Choi YS, Kim YW. An overview of the South Korean edible insect food industry: challenges and 
future pricing/promotion strategies. Entomol Res 2017;47:14151. https://doi.org/10.1111/1748-5967.12230

58. Elhassan M, Wendin K, Olsson V, Langton M. Quality aspects of insects as food-nutritional, sensory, and related concepts. Foods 2019;8:95. https://doi.org/10.3390/foods8030095

59. Melgar-Lalanne G, Hernández-Álvarez AJ, Salinas-Castro A. Edible insects processing: traditional and innovative technologies. Compr Rev Food Sci Food Saf 2019;18:1166-91. https:// doi.org/10.1111/1541-4337.12463

60. Mishyna M, Martinez JJI, Chen J, Benjamin O. Extraction, characterization and functional properties of soluble proteins from edible grasshopper (Schistocerca gregaria) and honey bee (Apis mellifera). Food Res Int 2019;116:697-706. https:// doi.org/10.1016/j.foodres.2018.08.098

61. Ribeiro JC, Cunha LM, Sousa-Pinto B, Fonseca J. Allergic risks of consuming edible insects: a systematic review. Mol Nutr Food Res 2018;62:1700030. https://doi.org/10.1002/mnfr. 201700030

62. Post MJ. Cultured meat from stem cells: challenges and prospects. Meat Sci 2012;2:297-301. https://doi.org/10.1016/j. meatsci.2012.04.008

63. Bhat ZF, Kumar S, Fayaz H. In vitro meat production: Challenges and benefits over conventional meat production. J Integr Agric 2015;14:241-8. https://doi.org/10.1016/S2095-3119(14) 60887-X

64. Kadim IT, Mahgoub O, Baqir S, Faye B, Purchas R. Cultured meat from muscle stem cells: a review of challenges and prospects. J Integr Agric 2015;14:222-33. https://doi.org/10.1016/ S2095-3119(14)60881-9

65.Heffernan, O. A meaty issue. Nature 2017;544:S18-S20. https:// doi.org/10.1038/544S18a

66. Choi KH, Yoon JW, Kim M, et al. Optimization of culture conditions for maintaining pig muscle stem cells in vitro. Food Sci Anim Resour 2020;40:659-67. https://doi.org/10.5851/ kosfa.2020.e39

67. Chriki, S, Hoequtte, JF. The myth of cultured meat: a review. Front Nutr 2020;7:7. https://doi.org/10.3389/fnut.2020.00007

68.Zhang G, Zhao X, Li X, Du G, Zhou J, Chen J. Challenges and possibilities for bio-manufacturing cultured meat. Trends Food Sci Technol 2020;97:443-50. https://doi.org/10.1016/ j.tifs.2020.01.026

69. Digital Food Lab. In 2040, clean meat will be the size of conventional meat [Internet]. Digital Food Lab; c2020 [cited 2020 June 5]. Available from: https://www.digitalfoodlab.com/2040- clean-meat-will-size-conventional-meat/

70.Specht EA, Welch DR, Clayton EMR, Lagally CD. Opportunities for applying biomedical production and manufacturing methods to the development of the clean meat industry. Biochem Eng J 2018;132:161-8. https://doi.org/10.1016/j.bej. 2018.01.015

71. Gaydhane MK, Mahanta U, Sharma CS, Khandelwal M, Ramakrishna S. Cultured meat: state of the art and future. Biomanuf Rev 2018;3:1. https://doi.org/10.1007/s40898-0180005-1

72. Bhat ZF, Fayaz H. Prospectus of cultured meat-advancing meat alternatives. J Food Sci Technol 2011;48:125-40. https:// doi.org/10.1007/s13197-010-0198-7

73.Stephens N, Di Silvio L, Dunsford I, Ellis M, Glencross A, Sexton A. Bringing cultured meat to market: technical, sociopolitical, and regulatory challenges in cellular agriculture. Trends Food Sci Technol 2018;78:155-66. https://doi.org/10. 1016/j.tifs.2018.04.010

74. Choi KH, Kim M, Yoon JW, et al. Purification of pig muscle stem cells using magnetic-activated cell sorting (MACS) based on the expression of CD29. Food Sci Anim Resour 2020 Jul 15 [Epub]. https://doi.org/10.5851/kosfa.2020.e51

75. Arshad MS, Javed M, Sohaib M, Saeed F, Imran A, Amjad Z. Tissue engineering approaches to develop cultured meat from cells: a mini review. Cogent Food Agric 2017;3:1320814. https:// doi.org/10.1080/23311932.2017.1320814

76.King JA, Miller WM. Bioreactor development for stem cell expansion and controlled differentiation. Curr Opin Chem Biol 2007;11:394-8. https://doi.org/10.1016/j.cbpa.2007.05. 034

77.Pörtner R, Nagel-Heyer S, Goepfert C, Adamietz P, Meenen NM. Bioreactor design for tissue engineering. J Biosci Bioeng 2005;100:235-45. https://doi.org/10.1263/jbb.100.235

78. Post MJ, Levenberg S, Kaplan DL, et al. Scientific, sustainability and regulatory challenges of cultured meat. Nat Food 2020;1: 403-15. https://doi.org/10.1038/s43016-020-0112-z

79. Fraeye I, Kratka M, Vandenburgh H, Thorrez L. Sensorial and nutritional aspects of cultured meat in comparison to traditional meat: much to be inferred. Front Nutr 2020;7:35. https://doi.org/10.3389/fnut.2020.00035

80.Dick A, Bhandari B, Prakash S. 3D printing of meat. Meat Sci 2019;153:35-44. https://doi.org/10.1016/j.meatsci.2019. 03.005 